\title{
PENGEMBANGAN LKPD BERBASIS PENDEKATAN SCIENCE, TECHNOLOGY, ENGINEERING, AND MATHEMATICS (STEM) UNTUK MENUMBUHKAN KETERAMPILANBERPIKIR KRITIS SISWA
}

\author{
Halim Simatupang ${ }^{1}$, Andika Sianturi ${ }^{1}$, Nanda Alwardah. $\mathbf{M}^{\mathbf{2}}$ \\ ${ }_{1}^{1}$ Program Studi Pendidikan Biologi, FMIPA, Universitas Negeri Medan, Jl. Willem Iskandar Psr. V, Medan Estate, \\ Medan, Indonesia, 20221 \\ 2Program Studi Pendidikan IPA, FMIPA, Universitas Negeri Medan \\ *Korespondensi Author: halim@unimed.ac.id
}

INFOARTIKEL

Histori Artikel

Received 23 Januari 2020

Revised 27 Januari 2020

Accepted 28 Januari 2020

Published 29 Januari 2020

Keywords:

LKPD, STEM, ADDIE, Berpikir

Kritis

\begin{abstract}
ABSTRAK
Penelitian ini bertujuan untuk merancang dan menghasilkan Lembar Kegiatan Peserta Didik (LKPD) berbasis Pendekatan Sains Technology Engineering and Mathematics (STEM) pada materi Perubahan Lingkungan. Desain penelitian yang digunakan adalah jenis penelitian dan pengembangan. Subjek dalam penelitian ini adalah Ahli Materi, Ahli Pembelajaran, Ahli Desain, Guru bidang studi Biologi dan siswa kelas X-MIA-1 SMA Swasta Parulian 1 Medan. Pengumpulan data dilakukan dengan instrumen berupa lembar tanggapan/respon. Analisis data menggunakan analisis deskriptif kuantitatif dan kualitatif. Perancangan LKPD berbasis Pendekatan STEM dilakukan dengan menggunakan model pengembangan instruksional ADDIE yaitu melalui tahap Analysis, Development, Implementation, dan Evaluation karena pada model ini setiap tahap dilaukan revisi hingga didapatkan produk LKPD yang lebih baik. Hasil penelitian menunjukkan bahwa perancangan LKPD berbasis Pendekatan STEM berdasarkan penilaian ahli materi diperoleh persentase rata-rata $94,64 \%$ dengan kriteria layak, penilaian ahli pembelajaran diperoleh persentase rata-rata $75 \%$ dengan kriteria layak, penilaian ahli desain diperoleh persentase rata-rata $76,78 \%$. Hasil dari penggunaan LKPD Berbasis Pendekatan STEM yang dirancang dalam menumbuhkan keterampilan berpikir kritis diperoleh skor rata-rata $82,57 \%$ dengan jumlah peserta didik yang tuntas sebanyak 25 orang. LKPD Berbasis STEM pada materi Perubahan Lingkungan yang telah dirancang memperoleh kriteria penilaian "sangat tinggi" dan telah memenuhi persyaratan efektif digunakan dalam menumbuhkan keterampilan berpikir kritis serta layak digunakan dalam proses pembelajaran Biologi pada materi perubahan lingkungan.
\end{abstract}

\section{ABSTRAK}

This study aims to design and produce Student Worksheets (LKPD) based on the Science Engineering Technology and Mathematics Approach (STEM) on the subject of Environmental Change. The research design used is a type of research and development. Subjects in this study were Material Experts, Learning Experts, Design Experts, Biology Study Teachers and X-MIA-1 Class Parulian 1 Private High School Medan. Data collection was carried out with instruments in the form of respons sheets. Data analysis used quantitative and qualitative descriptive analysis. The design of the LKPD based onthe STEM Approach was carried out using the ADDIE instructional development model, namely through the stages of Analysis, Development, Implementation, and Evaluation because in this model each stage was revised 
to get better LKPD products. The results showed that the design of the LKPD based on the STEM Approach based on the assessment of material experts obtained an average percentage of $94,64 \%$ with appropriate criteria, the assessment of learning experts obtained an average percentage of $75 \%$ with appropriate criteria, the design expert's assessment obtained an average percentage of $76,78 \%$ of the eligible criteria for the evaluation of Biology Study Teachers obtained an average percentage of $93.33 \%$ with a very feasible rating category, while the results of responses / responses from students obtained an average percentage of $95,82 \%$ with good assessment criteria. The results of the use of the LKPD Based on the STEM Approach designed to foster critical thinking skills obtained an average score of $82.57 \%$ with a total of 25 students completed. STEM-based LKPD on the material for Environmental Change that has been designed obtains "Very High" assessment criteria and has met the effective requirements used in fostering critical thinking skills and is suitable for use in the Biology learning process on environmental change material.

Copyright (C) 2019 Universitas Negeri Medan. Artikel Open Access dibawah lisensi CCBY-4.0 (https://creativecommons.org/licenses/by/4.0)

\section{How To Cite:}

Simatupang, H., Sianturi, A., \& M., NA. (2019). Pengembangan LKPD Berbasis Pendekatan Science, Technology, Engineering, And Mathematics (STEM) Untuk Menumbuhkan Keterampilanberpikir Kritis Siswa. Jurnal Pelita Pendidikan, 7(4), 170-177.

\section{PENDAHULUAN}

Peningkatan kualitas pendidikan di Indonesia bisa dikembangkan melalui penerapan reformasi pendidikan. Perubahan yang terjadi pada pembelajaran tradisional menuju pembelajaran yang lebih menumbuhkan daya berpikir kritis disebut dengan reformasi pendidikan (Redhana, 2010). Salah satu bentuk reformasi pendidikan dapat dilakukan dengan menggunakan pendekatan pembelajaran yang dapat membantu guru dalam menciptakan tenaga ahli yaitu pendekatan STEM (Science, Technology, Engeneering, and Mathematics). Pendekatan STEM ini adalah pendekatan yang merujuk kepada empat komponen ilmu pengetahuan, yaitu pengetahuan, teknologi, teknik, dan matematika Pendekatan STEM merupakan integrasi dari pembelajaran sains, teknologi, teknik, dan matematika yang disarankan untuk membantu kesuksesan keterampilan abad ke-21. (Brown, dkk, 2011, Pertiwi, 2017). Hal ini berarti bahwa melalui pendekatan STEM siswa tidak hanya sekedar menghafal konsep saja, tetapi lebih kepada bagaimana siswa mengerti dan memahami konsep-konsep sains dan kaitannya dalam kehidupan sehari-hari.
Berdasarkan observas yang dilakukan di SMA Swasta Parulian 1 Medan, pada kelas X-MIA ditemukan permasalahan dalam pembelajaran biologi adalah; 1) siswa kurang fokus saat pelajaran mengikuti pembelajaran; 2) daya mengingat siswa rendah; 3) siswa malu bertanya, 4) tingkat berpikir kritis siswa masih rendah, 5) kurang memperhatikan saat guru memberikan materi, 6) Guru belum sepenuhnya menggunakan LKPD saat proses pembelajaran, 7) LKPD yang ada disusun masih sederhana yang hanya berisi penyelesaian soal-soal kognitif saja. Permasalahan di atas terakumulasi yang mengakibatkan keterampilan berpikir kritis dilihat dari penyelesaian masalah dalam mengikuti pembelajaran biologi dilihat dari aktivitas pembelajaran siswa di kelas sangat rendah.

Dengan demikian pembelajaran yang seharusnya terpusat pada peserta didik belum sepenuhnya terwujud. Sehingga untuk mencapai keberhasilan pembelajaran, selain penggunaan pendekatan pembelajaran yang tepat, penggunaan bahan ajar pun harus sesuai agar berpikir siswa dapat meningkat. Bahan ajar memainkan peran penting dalam memastikan efektivitas kegiatan belajar mengajar, salah satunya adalah lembar 
kerja peserta didik (LKPD) (Pertiwi, 2017). Oleh karena itu, pengembangan LKPD yang disesuaikan dengan kondisi dan kebutuhan peserta didik dianggap perlu dilakukan.

Upaya menumbuhkan keterampilan berpikir kritis, pendidikan saat ini seharusnya mengarah pada proses pembelajaran yang menekankan pada masalah lingkungan hidup. Solusi yang dianggap sesuai untuk mengatasi masalah di atas adalah dengan menggunakan sebuah pendekatan pembelajaran dan bahan ajar yang sesuai sehingga mampu mendorong siswa membangun sikap ilmiah dalam berpikir kritis. Pendekatan pembelajaran STEM memberikan peluang kepada guru untuk memperlihatkan kepada peserta didik bahwa konsep, prinsip, sains, teknologi, engineering, dan matematika digunakan secara terintegrasi dalam pengembangan produk, proses, dan sistem yang digunakan dalam kehidupan sehari-hari mereka.

Sehingga berdasarkan pengamatan dan hasil pengumpulan data yang dilakukan maka penelitian ini bertujuan untuk; 1) mengetahui penilaian ahli materi terhadap kelayakan LKPD berbasis STEM yang dirancang pada materi perubahan lingkungan, 2) mengetahui penilaian ahli pembelajaran terhadap kelayakan LKPD berbasis STEM yang dirancang pada materi perubahan lingkungan, 3) mengetahui penilaian ahli desain terhadap kelayakan LKPD berbasis STEM yang dirancang pada materi perubahan lingkungan, 4) mengetahui penilaian guru terhadap kelayakan LKPD berbasis STEM yang dirancang pada materi perubahan lingkungan, 5) mengetahui tanggapan siswa terhadap LKPD berbasis STEM pada materi perubahan lingkungan yang dirancang dan 6) mengetahui efektifitas LKPD dalam menumbuhkan keterampilan berpikir kritis siswa pada pengembangan LKPD dengan pendekatan STEM pada siswa kelas X MIA SMA semester II.

\section{METODE PENELITIAN}

Penelitian ini menggunakan metode Kuantitatif dan kualitatif dimana data kuantitatif sendiri didapatkan dari hasil validasi ahli materi, ahli pembelajaran, ahli desain, penilaian guru dan data kualitatif sendiri dijabarkan dalam bentuk deskriftif yaitu dari hasil tanggapan siswa. Dan penelitian ini menggunakan pendekatan Penelitian dan Pengembangan (Research and Development) dengan model Analysis, Design, Development, Implementation, Evaluation (ADDIE). Penelitian dilakukan di SMA Swasta Parulian 1 Medan yang terletak di Jalan Stadion Teladan, Teladan Barat, Medan Kota, Kota Medan, Sumatra Utara. Sampel penelitian ini adalah kelas X MIA-1 yang berjumlah 28 siswa. Populasi penelitian ini yaitu seluruh kelas X MIA, dimana pengambilan sampel, diambil secara simple random sampling dilakukan dengan cara pengundian dan hasil undian yang didapat yaitu kelas X MIA-1.

Subjek penelitian adalah satu dosen biologi ahli, satu dosen biologi ahli pembelajaran, satu dosen ahli desain, satu guru biologi SMA Swasta Parulian 1 Medan, dan siswa kelas X MIA-1 SMA Swasta Parulian 1 Medan sebanyak 28 orang. Dimana pada penelitian ini digunakan satu kelas sebagai kelas eksperimen yang diajarkan dengan menggunakan LKPD STEM. Objek Penelitian dalam penelitian ini adalah kelayakan bahan ajar berupa LKPD dengan pendekatan STEM dengan tujuan untuk menumbuhkan keterampilan berpikir kritis siswa pada materi perubahan lingkungan pada siswa SMA kelas X MIA. Kelayakan bahan ajar tersebut dilihat dari segi kevalidan, dan keefektifan. 


\section{HASIL DAN PEMBAHASAN}

\section{Hasil Validasi LKPD oleh Ahli Materi}

Hasil persentase validasi ahli materi tehadap LKPD dapat dilihat pada tabel 1 dibawah ini.

Tabel 1. Persentase Hasil Validasi Ahli Materi

\begin{tabular}{l|c|l}
\hline Aspek Yang Dinilai & Persentase Rata-Rata & Kriteria \\
\hline Kelayakan Penyajian Materi & $96,75 \%$ & Sangat Layak \\
\hline Komponen STEM & $93,75 \%$ & Sangat Layak \\
\hline Penggunaan Bahasa & $\mathbf{8 7 , 5 \%}$ & Sangat Layak \\
\hline Rata-rata & $\mathbf{9 4 , 6 4 \%}$ & Sangat Layak \\
\hline
\end{tabular}

Berdasarkan Tabel 1. diketahui rata-rata persentase penilaian dari ahli materi berada dalam kategori "Sangat Layak" dengan persentase penilaian indikator kelayakan penyajian materi sebesar 96,75\%, indikator komponen STEM sebesar 93,75\%, dan indikator kebahasaan sebesar 87,5 \%. Persentase rata-rata kelayakan materi LKPD dengan pendekatan STEM pada materi Perubahan Lingkungan dari ahli materi 94,64 \% dengan kategori "Sangat Layak", sehingga bahan ajar yang telah dikembangkan dinyatakan layak digunakan. Jadi, dapat disimpulkan bahwa pada materi pada LKPD sudah sesuai dengan KI dan KD pada kurikulum 2013. Hal ini dikarenakan dalam penyusunan LKPD materi mengacu kepada tujuan pembelajaran dan indikator yang disesuaikan juga kepada KI dan KD. Menurut Depdiknas (2004) bahwa dengan adanya kompetensi dasar maka akan membantu peserta didik dalam proses pembelajaran serta peserta didik mampu mengetahui kemampuan mereka setelah melewati proses pembelajaran tersebut.

Pada LKPD ini sudah tertulis tentang kelayakan penyajian materi sesuai dengan $\mathrm{K}$ 1 tentang kekaguman dan rasa syukur terhadap Tuhan Yang Maha Esa melalui kolom refleksi yang tersedia. Dalam Permendikbud (2013), kegiatan pembelajaran $\mathrm{KI}-3$ dan $\mathrm{KI}-4$ menjadi tempat mengembangkan, $\mathrm{KI}-1$ berupa sikap spritual dan KI-2 berupa sikap sosial. Dan pada aspek kebahasaan, LKPD ditulis dengan bahasa yang lebih sederhana, jelas dan mudah dimengerti oleh peserta didik. Sehingga pada saat peserta didik menggunakan LKPD tersebut tidak akan terlalu sering bertanya kepada pendidik (Widjajanti, 2008). Serta dalam penggunaan bahasa yang baik juga harus memakai kaidah yang sesuai dengan EYD, KBBI, menggunakan bahasa baku dan tidak menafsirkan makna ganda dalam kalimat perintah yang tertulis pada LKPD.

\section{Hasil Validasi LKPD oleh Ahli Pembelajaran}

Hasil persentase validasi ahli pembelajaran tehadap LKPD dapat dilihat pada tabel 2 dibawah ini.

Tabel 2. Persentase Hasil Validasi Ahli Pembelajaran

\begin{tabular}{l|c|c}
\multicolumn{1}{c|}{ Aspek Yang Dinilai } & Persentase Rata-Rata & Kriteria \\
\hline Kelayakan Isi & $75 \%$ & Layak \\
\hline Komponen STEM & $75 \%$ & Layak \\
\hline Penggunaan Bahasa & $75 \%$ & Layak \\
\hline Rata-rata & $\mathbf{7 5 \%}$ & Layak \\
\hline
\end{tabular}


Berdasarkan Tabel 2. diketahui rata-rata persentase penilaian dari ahli pembelajaran berada dalam kategori "Layak" dengan persentase penilaian indikator kelayakan isi sebesar $75 \%$, indikator komponen STEM sebesar $75 \%$, dan indikator penggunaan bahasa sebesar $75 \%$. Secara keseluruhan Persentase rata-rata kelayakan pembelajaran LKPD dengan pendekatan STEM pada materi Perubahan Lingkungan dari ahli pembelajaran $75 \%$ dengan kategori "Layak", sehingga bahan ajar yang telah dikembangkan dinyatakan layak digunakan.

Komponen pembelajaran pada LKPD ini berbasis STEM, dimana aspek kelayakan isi yang dianalisis oleh ahli pembelajaran sudah memuat didalamnya konsep-konsep ataupun langkah-langkah pembelajaran STEM yang dimulai dari Sains sebagi metode ilmiah, Teknologi sebagai pemanfaatan teknologi, Teknik sebagai desain produk dan Matematikanya sebagai analisis data. Dan juga memuat indikatorindikator berpikir kritis serta materi utama tentang perubahan lingkungaSehingga ahli pembelajaran sendiri menganalisis dan memvalidasi hasil produk yang dihasilkan sebelum diuji kelayakannya kepada siswa untuk mencegah permasalahan yang tidak dikehendaki didalam pembelajaran. Seperti didukung dengan pendapat ahli (Kirschner, dkk, 2006) yang mengatakan bahwa pembelajaran STEM menuntut peserta didik berpikir secara mendalam untuk menyelesaikan permasalahan yang diberikan oleh guru dengan cara membuktikan melalui percobaan. Menurut Trianto (2014) dengan percobaan yang diberikan kepada peserta didik, diharapkan peserta didik memahami sendiri konsep dari hasil belajarnya tanpa diberitahu oleh guru.

\section{Hasil Validasi LKPD oleh Ahli Desain}

Hasil persentase validasi ahli desain tehadap LKPD dapat dilihat pada tabel 3 dibawah ini.

Tabel 3. Persentase Hasil Validasi Ahli Desain

\begin{tabular}{l|c|c}
\hline \multicolumn{1}{c|}{ Aspek Yang Dinilai } & Persentase Rata-Rata & Kriteria \\
\hline Penyajian Komponen & $81,25 \%$ & Layak \\
\hline Komponen STEM & $75 \%$ & Layak \\
\hline Kegrafikan & $75 \%$ & Layak \\
\hline Rata-rata & $\mathbf{7 6 , 7 8 \%}$ & Layak \\
\hline
\end{tabular}

Berdasarkan Tabel 3 diketahui ratarata persentase penilaian dari ahli desain berada dalam kategori "Layak" dengan persentase penilaian indikator penyajian komponen sebesar $81,25 \%$, indikator komponen STEM sebesar $75 \%$, dan indikator kegrafikan sebesar $75 \%$. Persentase ratarata kelayakan desain LKPD dengan pendekatan STEM pada materi Perubahan Lingkungan dari ahli desain 76,78 \% dengan kategori "Layak", sehingga bahan ajar yang telah dikembangkan dinyatakan layak digunakan. Penyajian komponen desain pada LKPD sudah baik artinya desain penampilan cover sudah representive untuk menyampaikan konsep atau isi dari LKPD tersebut ,kemudian identitas gambar, kesesuaian gambar memberikan gambaran nyata yang menunjukkan sesuatu objek yang sesungguhnya yang bisa menarik minat baca siswa, dan pengaturan pola/template pada LKPD sudah tersusun rapi dengan perpaduan warna yang harmonis. 
Dari kegrafikannya dilihat bahwa komposisi ukuran judul, gambar ilustrasi dan logo pada sampul LKPD sudah memuat didalamnya dengan runtun dan jelas,serta untuk penampilan LKPD secara umum sudah kreatif dan dinamis. Sesuai dengan penelitian (Umbaryati, 2016) gambar yang baik untuk LKPD adalah yang dapat menyampaikan pesan/isi dari gambar tersebut secara efektif kepada pengguna LKPD dan juga yang lebih penting adalah kejelasan isi atau pesan dari gambar itu secara keseluruhan.

\section{Keefektifan LKPD Dalam Menumbuhkan Keterampian Berpikir Kritis}

Keefektifan LKPD dalam menumbuhkan keterampilan berpikir kritis dilihat dari ketercapaian pelaksanan pembelajaran secara ketuntasan individu dan ketuntasan secara klasikal serta pengamatan aktitivas siswa dalam pembelajaran. Dari data hasil analisis penggunaan LKPD berbasis STEM dirancang pada kelompok kelas terbatas didapatkan skor rata-rata 82,57 dengan jumlah persentase ketuntasan sebesar $89,28 \%$. Data Interpretasi Nilai Akhir LKPD Terhadap Keefektifan LKPD Dalam Menumbuhkan Kemampuan Berpikir Kritis pada tabel 6, dan data Persentase Ketuntasan Hasil Belajar Kelas Terhadap Keefektifan LKPD Dalam Menumbuhkan Kemampuan Berpikir Kritis dapat dilihat pada Tabel 4.

Tabel 4. Interprestasi Nilai Akhir Tes Kemampuan Berpikir Kritis Terhadap Penggunaan LKPD.

\begin{tabular}{ccccc}
\hline No & Nilai Hasil Belajar & Kategori & Frekuensi & Persentase \\
\hline 1 & $81,25<x \leq 100$ & Sangat Tinggi & 16 & $57,14 \%$ \\
2 & $71,5<x \leq 81,25$ & Tinggi & 10 & $35,71 \%$ \\
3 & $62,5<x \leq 71,5$ & Sedang & 2 & $7,14 \%$ \\
4 & $43,75<x \leq 62,5$ & Rendah & 0 & $0 \%$ \\
5 & $0<x \leq 43,75$ & Sangat Rendah & 0 & $0 \%$ \\
\hline & Jumlah & & $\mathbf{2 8}$ & $\mathbf{1 0 0 \%}$ \\
\hline
\end{tabular}

Tabel 5. Persentase Ketuntasan Hasil Belajar Kelas Terhadap Keefektifan LKPD Dalam menumbuhkan Kemampuan Berpikir Kritis

\begin{tabular}{ccccc}
\hline No & Nilai Hasil Belajar & Kategori & Frekuensi & \multicolumn{2}{c}{ Persentase (\%) } \\
\hline 1 & $66-74$ & Tidak Tuntas & 3 & $10,71 \%$ \\
2 & $75-90$ & Tuntas & 25 & $89,28 \%$ \\
\hline Jumlah & & & $\mathbf{2 8}$ & $\mathbf{1 0 0 \%}$ \\
\hline
\end{tabular}




\section{Hasil Uji Coba Kelompok Terbatas Dalam Menumbuhkan Keterampian Berpikir Kritis}

Uji coba kelompok terbatas dilakukan di SMA Swasta Parulian 1 Medan. Uji coba ini dilakukan terhadap 28 orang siswa kelas X MIA-1 dengan kemampuan rendah, sedang, dan tinggi. Berdasarkan tabel 11, terlihat bahwa jumlah siswa yang tuntas hasil belajarnya 25 siswa dengan presentase $89,28 \%$ dan yang tidak tuntas hasil belajarnya 3 siswa dengan presentase 10,71\%, dimana pada siswa yang mendapatkan hasil yang tidak tuntas dikarenakan pada kegiatan Matematika pada LKPD proses pengerjaanya mendapatkan nilai yang rendah sehingga setelah dijumlah keseluruhan nilainya dari mulai kegiatan awal hingga akhir mendapatkan nilai dibawah KKM.

Berdasarkan tabel 10, terlihat bahwa kemampuan berpikir kritis siswa yang berada pada kategori "Sangat Rendah" $(0<x \leq 43,75)$ dan kategori "Rendah" 43,75<x $\leq 62,5$, tidak ada salah satupun siswa yang terdapat didalam kategori tersebut. Sedangkan kemampuan berpikir kritis siswa hanya menduduki kategori cukup sampai kategori sangat tinggi. Dimana kategori "Sedang" $62,5<x \leq 71,5$, yaitu sebanyak 2 siswa atau $7.14 \%$. Sedangkan siswa yang memiliki kemampuan berpikir kritis pada kategori "Tinggi" (71,5 < $\mathrm{x} \leq$ $81,25)$ sebanyak 10 siswa atau 35,71\%. Dan siswa yang memiliki kemampuan berpikir kritis siswa pada kategori "Sangat Tinggi" $(81,25<x \leq 100)$ sebanyak 16 siswa atau 57,14\%. dimana didalam kategori ini paling banyak siswa dibandingkan dengan kategori lainnya.

Sehingga skor rata-rata kemampuan berpikir kritis siswa sebesar 82,57 dengan jumlah persentase ketuntasan sebesar $89,28 \%$, yang berada pada kategori "Sangat Tinggi". Dan dapat disimpulkan bahwa sesuai teori yang mengatakan Pembelajaran dikatakan berhasil secara klasikal jika minimal $85 \%$ peserta didik mencapai tuntas, padahal data yang didapat jumlah persentase ketuntasan sebesar 89,28\%, sehingga LKPD yang diujikan kepada kelompok terbatas signifikan efektif dapat menumbuhkan keterampilan berpikir kritis siswa. Penggunaan suatu pendekatan dalam pembelajaran dapat mendukung peningkatan kemampuan berpikir kritis. LKPD sebagai bahan ajar pendukung yang mengintegrasikan STEM mencakup kegiatan siswa berupa mencoba, mengamati, menginterpretasi, menganalisis, dan menyimpulkan yang mendukung perkembangan berpikir kritis (Pangesti, dkk, 2017).

\section{KESIMPULAN}

Berdasarkan rumusan, tujuan, hasil dan pembahasan perancangan LKPD berbasis Pendekatan STEM pada materi Perubahan Lingkungan di kelas $X$ yang dikemukakan sebelumnya dapat disimpulkan Hasil penelitian menunjukkan bahwa perancangan LKPD berbasis Pendekatan STEM berdasarkan penilaian ahli materi diperoleh persentase rata-rata 94,64\% dengan kriteria layak, penilaian ahli pembelajaran diperoleh persentase rata-rata $75 \%$ dengan kriteria layak, penilaian ahli desain diperoleh persentase rata-rata $76,78 \%$. Hasil dari penggunaan LKPD Berbasis Pendekatan STEM yang dirancang dalam menumbuhkan keterampilan berpikir kritis diperoleh skor rata-rata $82,57 \%$ dengan jumlah peserta didik yang tuntas sebanyak 25 orang. LKPD Berbasis STEM pada materi Perubahan Lingkungan yang telah dirancang memperoleh kriteria penilaian "sangat tinggi" dan telah memenuhi persyaratan efektif digunakan dalam menumbuhkan keterampilan berpikir kritis serta layak digunakan dalam proses pembelajaran Biologi pada materi perubahan lingkungan.

\section{DAFTAR PUSTAKA}

Brown, R., Brown, J., Reardon, K., dan Merrill, C., (2011). Undestanding STEM.Curret

Perception. Tecnology and engineering Teacher.70 (15), 5-9.

Depdiknas. (2004). Permendiknas No.22 Tahun 2006 Tentang Standar Isi.

Jakarta: Depdiknas

Kirschner, P. A., Sweller, J.,\& Clark, R. E. (2006). Why Minimal Guidance During Instruction Does Not Work: An Analysis of the Failure of Contructivist, Discovery, Problem-Based, Exprential, and Inquiry-Based Teaching. Educational Psychologist. 41(2):75-86

Pangesti, K. I., Yulianti, D., \& Sugianto, S. (2017). Bahan Ajar Berbasis STEM (Science, Technology, Engineering, and Mathematics) untuk Meningkatkan Penguasaan Konsep 
Siswa SMA. UPEJ Unnes Physics Education Journal, 6(3), 53-58.

Pertiwi, R. S. (2017). Pengembangan Lembar Kerja Siswa Dengan Pendekatan Stem (Science, Technology, Engineering, Mathematics) Untuk Melatih Keterampilan Berpikir Kreatif Siswa Pada Materi Fluida Statis (diakses tanggal 30 Januari 2019).

Redhana, L. W. (2010). Program Pembelajaran Keterampilan Berpikir Kritis Pada Topik Laju Reaksi Untuk Siswa SMA. [Online] Tersedia di http://forumkependidikan.unsri.ac.id/userfi les/Artikel\%20l\%20Wayan\%2s ORedhanaLiliasari\%20UPG\&UPI\%20\%280K\%29-oknian.pdf. Diakses tanggal 30 Januari 2019.

Trianto. (2014). Mendesain Model Pembelajaran Inovatif-Progresif. Jakarta: Kencana.

Umbaryati, U. (2016). Pentingnya LKPD pada Pendekatan Scientific Pembelajaran Matematika. In PRISMA, Prosiding Seminar Nasional Matematika (pp. 217-225).

Widjajanti, E. (2008). Kualitas LKS. (online). http://staff.uny.ac.id. Diakses 24 Januari 2019 